DOI: 10.12731/2658-6649-2019-11-1-65-78

УДК 632.95. 619:616.995.42:615

\title{
ЭФФЕКТИВНОСТЬ ПРЕПАРАТОВ НА ОСНОВЕ ПРИРОДНЫХ БАВ ПРОТИВ ПАРАЗИТАРНОЙ ФАУНЫ РАСТЕНИЙ, ЖИВОТНЫХ И ПТИЦ
}

\section{Шаманская Л.Д., Бутаков Е.И.}

В статье приводятся результаты испытаний препаратов на основе природных БАВ: Афидин, Артафидин, Vita-Cтарт и Фос против паразитарной фауны растений, животных и птиц. Их эффективность против сосущих и листогрызущих вредителей растений на садовых и овощных культурах составляет 92,8-100\%. Они положительно влияют на рост и развитие растений, улучшают качество продукиии. Новые средства защиты безопасны для полезной фауны. Они обладают широким спектром действия и могут быть использованы для борьбы с эктопаразитами жсивотных и птии. 3а 1-2 обработки они позволяют на 100\% уничтожить эктопаразитов, паразитирующих на высокочувствительных кхимическим обработкам животных и птицах, к числу которых относятся кролики и домашняя птиия. Препараты на основе природных БАВ обладают принципиально новым, физическим механизмом действия, что исключает возможность развития устойчивости к ним у вредных организмов. Новые средства защиты безопасны для человека и окружающей среды, их применение позволяет снять цельй ряд ограничений, связанных с применением химических пестицидов.

Ключевые слова: растения; животные; эктопаразиты; препараты; эффективность; последействие.

\section{THE EFFICIENCY OF PREPARATIONS BASED ON NATURAL BIOLOGICALLY ACTIVE SUBSTANCES AGAINST PARASITIC FAUNA OF PLANTS, ANIMALS AND BIRDS}

\section{Shamanskaya L.D., Butakov E.I.}

The article presents the results of tests of preparations based on natural biologically active substances: Afidin, Artafidin, Vita-Cmapm and Fos against parasitic fauna of plants, animals and birds. Their effectiveness against sucking and leaf-eating plant pests in garden and vegetable crops is $92.8-100 \%$. 
They have a positive effect on the growth and development of plants, improve product quality. New means of protection are safe for useful fauna. They have a wide range of actions and can be used to fight against ectoparasites of animals and birds. For 1-2 treatments, they allow 100\% to destroy ectoparasites, been parasites by animals and birds of highly sensitive to chemical treatments, which include rabbits and poultry. Preparations based on natural biologically active substances possess entirely new physical mechanism of action that eliminates the possibility of development of resistance to them from prejudicial organisms. New means of protection are safe for humans and environment, their application allows to reduce a number of restrictions connected with application of chemical pesticides.

Keywords: plants; animals; ectoparasites; preparations; efficiency; aftereffect.

\section{Введение}

Современные методы защиты растений, животных и птиц от паразитарной фауны основываются на преимущественном использовании химических пестицидов. Их отрицательное действие общеизвестно. Они обладают высокой токсичностью, кумулятивными свойствами, мутагенной и канцерогенной активностью, оказывают разрушительное действие на экосистему [1-2]. Многолетнее использование химических пестицидов в агроценозах садовых культур сопровождается уничтожением специализированных видов паразитов и хищников, способствует формированию резистентных популяций вредителей. В настоящее время резистентность вредных организмов стала одной из важных проблем, определяющих эффективность земледелия [3]. Решить эту проблему при использовании химических пестицидов не удается в связи с тем, что происходит постоянный процесс опережающей эволюции новых устойчивых видов вредных организмов, и как следствие, увеличение пестицидной нагрузки в экосистемах [4].

Проблема развития устойчивости не менее актуальна при использовании химических пестицидов в животноводстве и птицеводстве. Применение химических средств защиты в этих отраслях имеет целый ряд ограничений. В настоящее время нет эффективных и одновременно безопасных препаратов для обработки особо чувствительных к пестицидам животных и птиц, к числу которых относятся кролики и домашняя птица.

Это вызывает необходимость разработки новых препаратов защитного действия, исключающих негативные последствия использования химических пестицидов. 
Подобные препараты, на основе природных БАВ защитного и иммуномодулирующего действия разработаны в нашей стране и за рубежом [512]. Это направление исследований в защите растений в настоящее время считается наиболее перспективным [13-15]. В структуре средств защиты растений на долю препаратов на основе природных БАВ в нашей стране приходится не более $8 \%$, причем большая часть из них фунгицидного и фунгистатического действия. В связи с этим актуален вопрос разработки экологически безопасных препаратов инсекто-акарицидной активности.

На протяжении многих лет исследований разработка подобных препаратов на основе природных БАВ проводились в НИИ садоводства Сибири им М.А. Лисавенко.

С учетом сходства в морфологии и физиологии вредителей растений и эктопаразитов животных и птиц в задачи настоящих исследований входило:

1 - Определить эффективность новых средств защиты против широкого круга представителей паразитарной фауны.

2 - Изучить последействие обработки на защищаемые объекты.

3 - Определить действие препаратов на полезную фауну и возможность формирования резистентных популяций вредителей

\section{Материалы и методы}

Основные исследования проводили в НИИСС им. М.А. Лисавенко, во Всероссийском НИИ ветеринарной Энтомологии и арахнологии, Алтайском научно-исследовательском институте сельского хозяйства (ФГБНУ Алтайский НИИСХ) в 2006-2017 гг.

Объекты исследований: сосущие и листогрызущие вредители растений, эктопаразиты животных и птиц, препараты на основе природных БАВ, представляющие собой концентраты эмульсий и содержащие в своём составе липиды, фосфолипиды, хитозан и другие активные компоненты, безопасные для человека и окружающей среды. Механизм действия препаратов физический. Он основан на закупорке дыхалец сосущих и кровососущих вредителей мельчайшими каплями масла с конечным эффектом гипоксии. Арахидоновая кислота в составе препаратов обеспечивает дополнительный инсектицидный эффект против листогрызущих вредителей. Препараты испытаны в концентрациях от 0,005 до 2\%, в защищённом грунте в трёх кратном повторении, в полевых условиях в четырех кратном. В качестве эталона испытаны: химический препарат Актеллик и Инсектицидное мыло. 
В тепличных условиях обработку растений проводили из опрыскивателя Electronic с нормой расхода рабочей жидкости 2 л/м². Обработку яблони сорта Заветное проводили в течение 5 лет от начала посадки, включая 3 года плодоношения. Яблоню обрабатывали из опрыскивателя Kwasar c нормой расхода 0,2-2,5 л на 1 растение. В опытах использовали растения, зараженные в средней и сильной степени. Гибель вредителей учитывали на второй день после обработки по методике К.А. Гара [16]. Последействие обработки на развитие растений определяли в конце вегетации путем измерения однолетнего прироста и учета урожайности на двух модельных растениях в каждом повторении. Биохимический анализ плодов проводили в лаборатории биохимии НИИСС по общепринятым методикам. Экспериментальные данные обработаны методом дисперсионного анализа [17].

Сбор, хранение и определение видовой принадлежности пухопероедов и клещей проводили по методикам, описанным Е.Н. Павловским [18], Д.И. Благовещенским [19].

Испытание препаратов против эктопаразитов животных проводили по методикам, описанным Г.И. Вольскис [20] и Дезинсекция: Методы определения эффективности инсектицидов, акарицидов, регуляторов развития и репеллентов, используемых в медицинской дезинсекции [21].

Цифровые данные обрабатывали методами математической статистики в среде программных приложений Microsoft Excel и Stat Soft Statistic.

\section{Результаты исследований}

Против тлей на основе растительных липидов разработан препарат Афидин, в состав которого входит стимулятор роста растений. Его эффективность против различных видов тлей в условиях открытого и защищенного грунта составила 95-100\% (табл. 1).

Таблицуа 1.

Эффективность Афидина против различных видов тлей

\begin{tabular}{|c|c|c|c|c|}
\hline \multirow[b]{2}{*}{ Культура } & \multirow[b]{2}{*}{ Виды тлей } & \multicolumn{3}{|c|}{ Гибель тлей и энтомофагов, \% } \\
\hline & & $\begin{array}{c}\text { Афидин } \\
1 \%\end{array}$ & $\begin{array}{c}\text { Актеллик } \\
0,1 \%\end{array}$ & Контроль \\
\hline \multicolumn{5}{|c|}{ Открытый грунт } \\
\hline Смородина & крыжовниковая & 97,0 & 100 & 2,4 \\
\hline Яблоня & зеленая яблонная & 100 & 100 & 0,6 \\
\hline Облепиха & зелёная облепихов. & 100 & 100 & 3,7 \\
\hline
\end{tabular}


Окончание табл. 1.

\begin{tabular}{|c|c|c|c|c|}
\hline Слива & сливовая & 95,0 & 98,0 & 0,6 \\
\hline Калина & калиновая & 98,0 & 99,0 & 1,2 \\
\hline \multicolumn{5}{|c|}{ Защищенный грунт } \\
\hline Перец & персиковая & 100 & 100 & 0,9 \\
\hline Роза & персиковая & 100 & 100 & 3,4 \\
\hline Огурец & бахчевая & 96,0 & 100 & 0 \\
\hline Томаты & большая картоф. & 98,0 & 100 & 0 \\
\hline \multicolumn{5}{|c|}{ Энтомофаги, акарифаги } \\
\hline \multirow{4}{*}{$\begin{array}{l}\text { Смородина, } \\
\text { Яблоня, } \\
\text { Огурец, } \\
\text { Капуста }\end{array}$} & \multirow{4}{*}{$\begin{array}{c}\text { наездники, хищные клещи, } \\
\text { златоглазки, кокцинеллиды, } \\
\text { мухи-журчалки и личинки } \\
\text { хищной галлицы }\end{array}$} & 0 & 100 & 0,1 \\
\hline & & 0 & 100 & 0 \\
\hline & & 0 & 100 & 0 \\
\hline & & 0 & 100 & 0 \\
\hline
\end{tabular}

При испытании Афидина в условиях открытого и защищенного грунта выявлено его избирательное действие по отношению к полезной фауне. На фоне обработки Афидином паразиты и хищники сохраняли свою жизнеспособность, в то время как химический препарат Актеллик полностью их уничтожал.

При испытании Афидина против бахчевой (Aphis gossypii Glover) и капустной (Brevicoryne brassicae Linnaeus) тли на Западно-Сибирской овощной опытной станции его эффективность в оптимальной концентрации $1 \%$ составила 99,8-100\%. При этом на фоне обработки Афидином отмечался активный лет паразита Афидиуса, в то время как при обработке Актелликом лет энтомофага не наблюдался (табл. 2).

Таблиияа 2.

Эффективность Афидина против тлей на овощных культурах

\begin{tabular}{|c|c|c|c|c|}
\hline \multirow{2}{*}{ Вариант } & Концен- & \multicolumn{2}{|c|}{ Гибель тлей, \% } & \multirow{2}{*}{ Примечание } \\
\cline { 3 - 4 } & трация, & бахчевой & капустной & \\
\hline Без обработ. - контроль & - & 2,3 & 1,8 & лет паразита \\
\hline Актеллик (эталон) & 0,2 & 100 & 100 & отсутствие лета \\
\hline \multirow{2}{*}{ Афидин } & 0,5 & 90,5 & 85,3 & лет паразита \\
\cline { 2 - 4 } & 1 & 99,8 & 100 & лет паразита \\
\cline { 2 - 4 } & 2 & 100 & 100 & лет паразита \\
\hline
\end{tabular}

Афидин эффективен и против других сосущих вредителей. По результатам испытаний во Всероссийском селекционно-технологическом институте садоводства и питомниководства, проведенным Наумовой 
Л.В. эффективность этого препарата против акациевой ложнощитовки (Parthenolecanium corni Bouche) на жимолости составила 95,5\%.

При испытании Афидина (1\%) в многолетнем стационаре яблони отмечено стимулирующее действие препарата на рост и развитие растений. Прибавка урожая по отношению к контролю статистически достоверна и составила при обработке Афидином 101\%, Актелликом - 88\%.

Биохимический анализ плодов показал повышение содержания сахара до $12,9 \%$, пектинов до 0,9\% при обработке яблони Афидином против $9,8 \%$ и $0,5 \%$ в контроле. Максимальный показатель сахаро-кислотного индекса - 27,5 ед. против 13,8\% в контроле, получен на фоне обработки Афидином, что свидетельствует об улучшении вкусовых качеств плодов и важно при их употреблении в свежем виде.

На четвертый год выращивания яблони, на фоне обработки Актелликом, было отмечено снижение эффективности против зеленой яблонной тли до 48,1\%, в то время как при обработке Афидином гибель вредителя оставалась высокой - 98,2\%. Это свидетельствует о развитии устойчивости у целевого объекта к химическому препарату Актеллику. Для подтверждения полученного результата на следующий год обработку растений Афидином и Актелликом повторили на стационарном участке и в посадках яблони, где эти препараты ранее не применялись. Результаты учетов показали, что эффективность Актеллика и Афидина на участке, где препараты ранее не применялись, составила 99,1-100\%, в то время как на стационарном участке на фоне обработки Актелликом она снизилась до $43,2-46,4 \%$ (табл. 3 ).

Таблицуа 3.

Эффективность Афидина против зеленой яблонной тли на разных фонах обработки

\begin{tabular}{|l|c|c|c|c|c|}
\hline \multirow{2}{*}{ Вариант } & \multirow{2}{*}{$\begin{array}{c}\text { Концент- } \\
\text { рация, \% }\end{array}$} & \multicolumn{4}{|c|}{ Гибель тлей, \% } \\
\cline { 3 - 6 } & & 14.06 & 12.07 & 14.06 & 12.07 \\
\hline Без обработки - контроль & - & 0,2 & 0,6 & 0,5 & 0,3 \\
\hline Актеллик - 0,1\% (эталон) & 0,1 & 43,2 & 46,4 & 99,6 & 100 \\
\hline Афидин - 1\% & 1,0 & 98,8 & 97,6 & 100 & 99,1 \\
\hline НСР $_{05}$ & - & 23,4 & 38,6 & 22,8 & 32,1 \\
\hline
\end{tabular}

Результаты этого опыта подтверждают, что на фоне обработки Афидином не отмечено формирование устойчивости у целевого объекта к этому препарату. На основе хитозана в НИИ садоводства Сибири разработан 
препарат Артафидин, содержащий в своем составе арахидоновую кислоту, комплекс микро- и макроэлементов.

Против тлей на садовых культурах его эффективность в оптимальной концентрации 1\% составила 96,9-100\% (табл. 4).

Таблийа 4.

Эффективность Артафидина против различных видов тлей

\begin{tabular}{|c|c|c|c|c|c|c|}
\hline \multirow{2}{*}{ Препараты } & $\begin{array}{c}\text { Кон- } \\
\text { цен- } \\
\text { трация, } \\
\%\end{array}$ & $\begin{array}{c}\text { кали- } \\
\text { но- } \\
\text { вой }\end{array}$ & $\begin{array}{c}\text { зеленой } \\
\text { яблон- } \\
\text { ной }\end{array}$ & $\begin{array}{c}\text { сливо- } \\
\text { вой по- } \\
\text { лосатой }\end{array}$ & $\begin{array}{c}\text { виш- } \\
\text { невой }\end{array}$ & $\begin{array}{c}\text { кры- } \\
\text { жовни- } \\
\text { ковой }\end{array}$ \\
\hline Контроль- без обработки & - & 2,5 & 0,3 & 0,8 & 43,1 & 0,1 \\
\hline \multirow{2}{*}{ Инсектицид. мыло (эталон) } & 1 & 98,6 & 99,8 & 90,6 & 89,1 & 93,6 \\
\cline { 2 - 7 } & 2 & 99,4 & 100 & 98,9 & 98,9 & 100 \\
\hline \multirow{3}{*}{ Артафидин } & 0,5 & 88,9 & 85,4 & 86,7 & 70,4 & 74,5 \\
\cline { 2 - 7 } & 1 & 96,9 & 99,7 & 100 & 100 & 97,7 \\
\cline { 2 - 7 } & 2 & 97,8 & 99,2 & 100 & 100 & 99,3 \\
\hline $\mathrm{HCP}_{05}$ & - & 7,3 & 21,4 & 7,9 & 12,6 & 33,9 \\
\hline
\end{tabular}

При испытании на садовых культурах Артафидин показал избирательное действие на полезную фауну, представленную хищными клещами, личинками хищных галлиц, мух журчалок и кокцинеллид.

На овощных культурах против капустной и бахчевой тли Артафидин показал эффективность на уровне 97,4-100\%, при обработке инсектицидным мылом, испытанным в качестве эталона 70,4-90,1\%. На фоне обработки Артафидином личинки хищной галлицы полностью сохраняли свою жизнеспособность, в то время как инсектицидное мыло вызвало их гибель на уровне $35,8 \%$.

При испытании Артафидина в многолетнем стационаре яблони против зеленой яблонной тли выявлено положительное действие препарата на рост и развитие растений. На этом фоне обработки отмечено повышение сахаристости плодов, содержания витамина С и суммы пектинов по сравнению с контролем. Показатель сахаро-кислотного индекса на фоне обработки Артафидином составил 14,1 ед. против 7,4 ед. в контроле, что свидетельствует о значительном улучшении вкусовых качеств плодов. У целевого объекта - зеленой яблонной тли не отмечено формирования устойчивости к этому препарату.

Против листогрызущих вредителей, в частности против гусениц боярышницы (Aporia crataegi Linnaeus) младших возрастов, в опытах in vitro эффективность этого препарата составила 98,2-100\%. 
Следующий препарат, разработанный в НИИ садоводства Сибири VitaСтарт содержит в своем составе липиды животного происхождения и арахидоновую кислоту. При испытании в многолетнем стационаре яблони в концентрации 0,005 и 0,2\% выявлено иммуномодулирующее действие этого препарата $(0,2 \%)$ в отношении зеленой яблонной тли, что обеспечивает длительный защитный эффект от этого вредителя на фоне однократного опрыскивания (рис. 1).

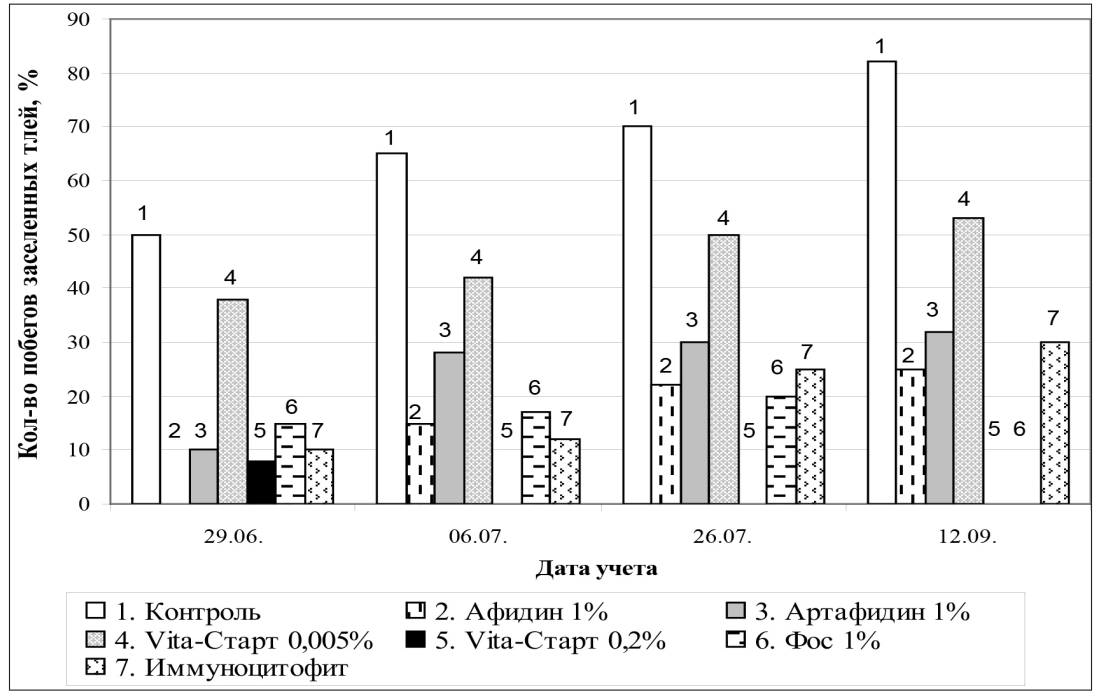

Рис. 1. Заселённость яблони тлей на различных фонах обработки

В опытах in vitro Vita-Старт (0,3\%) показал $100 \%$ эффективность против гусениц капустной белянки (Pieris brassicae Linnaeus).

На основе фосфолипидов нами разработан препарат Фос. При испытании в многолетнем стационаре яблони его эффективность против зеленой яблонной тли приближалась к абсолютной. При этом численность сопутствующего объекта - яблонного листового клеща (Calepitrimerus baileyi Keifer) снизилась до хозяйственно неощутимого уровня, что свидетельствует об акарицидной активности препарата.

При испытании в многолетнем стационаре яблони Фос показал избирательное действие на полезную фауну, полностью сохраняя жизнеспособность полезной биоты. В опытах in vitro его эффективность против гусениц боярышницы ранних возрастов составила 92,8-100\%. 
Дальнейшие испытания препаратов, разработанных на основе природных БАВ показали, что они обладают широким спектром действия и могут быть использованы для борьбы с эктопаразитами животных. Исследования, проведенные во Всероссийском НИИ ветеринарной энтомологии и арахнологии показали, что двукратная обработка Артафидином полностью излечивает кроликов от псороптоза, связанного с паразитированием накожникового клеща Psoroptes cuniculi Delaform (табл. 5).

Таблица 5 .

Эффективность Артафидина против псороптоза кроликов

\begin{tabular}{|c|c|c|c|}
\hline \multirow{2}{*}{$\begin{array}{c}\text { Препараты, } \\
\text { концентрация }\end{array}$} & \multicolumn{3}{|c|}{$\begin{array}{c}\text { Гибель клещей при разной степен. поражения } \\
\text { псороптозом, \% }\end{array}$} \\
\hline & легкая & средняя & тяжелая \\
\hline Контроль, вода & 0 & 0 & 0 \\
\hline $\begin{array}{c}\text { Гипхлофос + рас. масло - } \\
15 \% \text { (эталон) }\end{array}$ & 100 & 100 & 100 \\
\hline Артафидин - 4\% & 100 & 100 & 100 \\
\hline Артафидин - 8\% & 100 & 100 & 100 \\
\hline
\end{tabular}

В ветеринарии двукратная обработка Vita-Стартом полностью излечивает кроликов от нотоэдроза, связанного с паразитированием чесоточного клеща нотоэдроз (Notoedres cuniculi Railliet) (табл. 6).

Таблицуа 6.

Эффективность препарата Vita-Старт против нотоэдроза

\begin{tabular}{|c|c|c|c|}
\hline \multirow{2}{*}{ Вариант } & \multicolumn{3}{|c|}{$\begin{array}{r}\text { Гибель клещей при различной степени поражения } \\
\text { кроликов нотоэдрозом, \% }\end{array}$} \\
\cline { 2 - 4 } & легкая & средняя & тяжелая \\
\hline Без обработки - контроль & 0 & 0 & 0 \\
\hline Vita-Старт $-4 \%$ & 79,2 & 53,0 & 0 \\
\hline Vita-Старт $-8 \%$ & 100 & 100 & 100 \\
\hline
\end{tabular}

При испытании Артафидина и Vita-Старта против чесоточных клещей, вызывающих псороптоз и нотоэдроз, не отмечено отрицательного действия обработки этими препаратами на животных.

Испытания, проведенные сотрудниками Роспотребнадзора по республике Алтай показали, что препарат Фос эффективен против иксодовых клещей: лугового (Dermacentor reniculatus Fabricius) и степного (Dermacentor magrinatus Sulzer) - переносчиков многих инфекционных заболеваний человека и животных. Однократная обработка пастбищ этим препаратом уничтожает паразитов на $78,4 \%$, что значительно сокращает риск нападения клещей на животных (табл. 7). 
Таблица 7.

Эффективность препаратов против иксодовых клещей на пастбищных участках

\begin{tabular}{|c|c|c|c|c|c|c|}
\hline \multirow{2}{*}{ Препарат, концентрация } & \multicolumn{2}{|c|}{$\begin{array}{c}\text { Численность } \\
\text { ч/3 } 24 \text { часа }\end{array}$} & \multicolumn{2}{|c|}{$\begin{array}{c}\text { Численность } \\
\text { ч/3 } 48 \text { часа }\end{array}$} & \multicolumn{2}{|c|}{$\begin{array}{l}\text { Численность } \\
\text { ч/3 } 72 \text { часа }\end{array}$} \\
\hline & эКз. & $\begin{array}{l}\text { сниже- } \\
\text { ние, \% }\end{array}$ & эКз. & $\begin{array}{l}\text { сниже- } \\
\text { ние, \% }\end{array}$ & эКз. & $\begin{array}{l}\text { сниже- } \\
\text { ние, \% }\end{array}$ \\
\hline $\begin{array}{c}\text { Контроль - } \\
\text { без обработки }\end{array}$ & 172 & - & 178 & - & 160 & 4,2 \\
\hline Бриз-1,25\% (эталон) & 48 & 71,3 & 37 & 77,8 & 40 & 76,0 \\
\hline$\Phi$ oc $-2 \%$ & 50 & 71,1 & 41 & 75,4 & 36 & 78,4 \\
\hline Фитоверм - 0,3\% & 42 & 74,9 & 39 & 76,6 & 48 & 71,3 \\
\hline
\end{tabular}

При использовании препарата для обработки непосредственно животных его эффективность составила $100 \%$.

Фос может быть использован и для защиты от нападения клещей на мелких домашних животных. Экспериментально доказано, что обработка выгульных площадок этим препаратом полностью предохраняет собак от нападения клещей.

Высокая чувствительность к препаратам на основе природных БАВ, с гибелью паразита на уровне $100 \%$, как в высоких, так и предельно низких концентрациях, выявлена при их испытании против пухопероеда (Menacanthus stramineus Nitzsch), паразитирующего на домашней птице (табл. 8).

Таблица 8.

Эффективность препаратов на основе природных БАВ против Menacanthus stramineus

\begin{tabular}{|c|c|c|c|c|c|c|c|c|c|}
\hline \multirow{2}{*}{ Препарат } & \multicolumn{8}{|c|}{ Гибель пухопероеда, \% } \\
\cline { 2 - 12 } & $4-1$ & 0,5 & 0,25 & 0,1 & 0,05 & 0,025 & 0,01 & 0,001 & 0,0005 \\
\hline Афидин & 100 & 100 & 100 & 100 & 100 & 100 & 100 & 100 & 100 \\
\hline Артафидин & 100 & 100 & 100 & 100 & 100 & 100 & 100 & 100 & 100 \\
\hline Vita-Старт & 100 & 100 & 100 & 100 & 100 & 100 & 100 & 100 & 100 \\
\hline Фос & 100 & 100 & 100 & 100 & 100 & 100 & 100 & 100 & 100 \\
\hline Кео & 100 & 100 & 100 & 100 & 100 & 100 & 100 & 100 & - \\
\hline Формицид & 100 & 100 & 100 & 100 & 100 & 100 & 100 & 100 & 100 \\
\hline $\begin{array}{c}\text { Неостомазан } \\
\text { (эталон) }\end{array}$ & - & - & - & - & - & - & - & 100 & - \\
\hline $\begin{array}{c}\text { Без обработки - } \\
\text { контроль }\end{array}$ & \multicolumn{10}{|c|}{$0,09-0,4$} \\
\hline
\end{tabular}


Из них наиболее простым и дешевым средством защиты от этого паразита является препарат Формицид, разработанный на основе органических кислот. При производственном испытании Формицида на «Благовещенской» птицефабрике Алтайского края получена 100\% эффективность обработки домашней птицы от пухопероеда и длительное защитное действие, что свидетельствует об овицидной активности препарата.

\section{Выводы}

Препараты на основе природных БАВ разработанные в НИИ садоводства Сибири не содержат в своем составе токсичных компонентов, поэтому они безопасны для человека и окружающей среды.

По своей эффективности новые препараты не уступают химическим средствам защиты и в отличие от них обладают избирательным действием на полезную фауну, что позволяет сохранять природное равновесие в агроценозах садовых культур

Содержание в составе препаратов стимуляторов роста положительно влияет на рост и развитие растений, улучшает качество продукции.

Средства защиты растений на основе природных БАВ обладают принципиально новым, физическим механизмом действия, что исключает возможность развития устойчивости к ним у вредных организмов.

Препараты на основе природных БАВ обладают широким спектром действия и могут быть использованы не только в защите растений, но и в качестве средств защиты животных и птиц от эктопаразитов.

\section{Список литературы}

1. Черменский Д.И., Непоклонов А.А., Брюшинина и др. Отбор актиномицетов продуцентов биопестицидов //Агрохимия, 1989. № 1. С. 89-94.

2. Мельников Н.Н. Пестициды и окружающая среда //Защита растений, 1989. № 4. C. 4-8.

3. Вошедский Н.Н., Махоткин А.Г., Зверев А.А., Махоткина Л.Я. Резистентность колорадского жука к пиретроидам в Ростовской области: материалы 9-го совещания «Современное состояние проблемы резистентности вредителей, возбудителей болезней и сорняков в России и сопредельных странах на рубеже XXI века». С. Петербург, 2000. С. 34.

4. Захаренко В.А., Захаренко А.А. Экономические и экологические проблемы использования пестицидов //Защита растений, 1995. № 3. С. 10-11.

5. Baxendale R.W., Johnson W.T. Efficacy of summer oil spray on thirteen commonly occurring insect pests. // I. Arboic, 1990. Vol.16. № 4, pp. 89-94. 
6. Besselte Steven M., Beigler Myron A. Non-hazardous pest control: Пат. 6183767 США. МПК ${ }^{7}$ А 01 № 25/32. Ecosmart Technologies. Inc. № 09/056712; Заявл. 08.04.98. Опублик. 06.02.01. НПК 424/406.

7. Nakashita H., Yoshioka et al. Probenazole induces systemic acquired resistance in tobacco through salicylic acid accumulation // Physiol. Mol. Plant Pathol., 2002. 61, pp. 197-203.

8. Reignault P, Walters D. In., Walters R., Newton A., Lyon G. Topcal application of inducers for disease control // Induced resistance for Plant Defense: A Sustainable Approach to Protection, Oxford, Blackwell, Publishing Ltd., 2007, pp. 179-200.

9. Захаренко В.А. Продукты растительного происхождения для производства пестицидов // Защита и карантин растений, 2003. № 5. С. 49-50.

10. Юрченко О.С., Селицкая О.Г., Буров В.Н., Тютерев С.Л. Энтомологическое обозрение, 2004. Т. 83, № 4. С. 808-815.

11. Кириллова О.С., Селицкая О.Г. Циркон как иммуномодулятор устойчивости огурца к фитофагам // Вестник защиты растений, 2015. № 1 (83). С. 58-62.

12. Тютерев С.Л. Экологически безопасные индукторы устойчивости растений к болезням и физиологическим стрессам // Вестник защиты растений, 2015. № 1 (83). C. 3-13.

13. Власенко Н.Г., Малюга А.А., Егорычева М.Т. и др. Перспективные препараты для защиты сельскохозяйственных культур в Западной Сибири // Биологическая защита растений - основа стабилизации агроэкосистем; Всероссийский научно-исследовательский институт биологической защиты растений. Краснодар, 2012. Вып. 7. С. 314-316.

14. Вакуленко В.В. Регуляторы роста и микроудобрения - факторы повышения продуктивности культур //Защита и карантин растений, 2015. № 3. С. 43.

15. Gvozdenac S., Indie D., Vukovic S. et al. Botanical insecticides and their use in plant protection // Bitjni Lekar, 2013. Vol. 41, № 5, pp. 548-557.

16. Гар К.А. Методы испытания токсичности и эффективности пестицидов. M., 1963. 286 c.

17. Доспехов Б.А. Методика полевого опыта. М.: Колос, 1986. 502 с.

18. Павловский Е.Н. Насекомые, пухоеды // Фауна СССР. М.-Л., 1959. Т. 1. Вып. 1. Ч. 1. 202 c.

19. Благовещенский Д.И. Методы исследования вшей (Siphunculata)/Д.И. Благовещенский. Л.: Наука. 1972. 88 с.

20. Вольскис Г.И. Методические указания по сбору материала для исследования болезней птиц и их возбудителей // Методики исследования продуктивности и структуры видов птиц в пределах их ареалов. Вильнюс, 1977. Ч. 1. C. $121-127$. 
21. Дезинсекция: Методы определения эффективности инсектицидов, акарицидов, регуляторов развития и репеллентов, используемых в медицинской дезинсекции. М., 2003. 87 с.

\section{References}

1. Chermenskij D.I., Nepoklonov A.A., Bryushinina et al. Agrohimiya, 1989. № 1, pp. 89-94.

2. Melnikov N.N. Zashchita rastenij, 1989. № 4, pp. 4-8.

3. Voshedskij N.N., Mahotkin A.G., Zverev A.A., Mahotkina L.YA. Rezi-stentnosti koloradskogo zhuka $k$ piretroidam $v$ Rostovskoj oblasti: materialy 9-go soveshchaniya «Sovremennoe sostoyanie problemy rezistentnosti vreditelej, vozbuditelej boleznej i sornyakov v Rossii i sopredel'nyh stranah na rubezhe XXI veka» [Resistance of the Colorado potato beetle to pyrethroids in the Rostov region: proceedings of the 9th meeting "The current state of the problem of resistance of pests, pathogens and weeds in Russia and neighboring countries at the beginning of the 21 st century"']. S. Peterburg, 2000. P. 34.

4. Zaharenko V.A., Zaharenko A.A. Zashchita rastenij, 1995. № 3, pp. 10-11.

5. Baxendale R.W., Johnson W.T. Efficacy of summer oil spray on thirteen commonly occurring insect pests. I. Arboic, 1990. Vol.16. № 4, pp. 89-94.

6. Besselte Steven M., Beigler Myron A. Non-hazardous pest control: Pat. 6183767 SSHA. MPK7 A 01 № 25/32. Ecosmart Technologies. Inc. № 09/056712; Zayavl. 08.04.98. Opublik. 06.02.01. NPK 424/406.

7. Nakashita H., Yoshioka et al. Probenazole induces systemic acquired re-sistance in tobacco through salicylic acid accumulation. Physiol. Mol. Plant Pathol., 2002. 61, pp. 197-203.

8. Reignault P., Walters D. In., Walters R., Newton A., Lyon G. Topcal application of inducers for disease control. Induced resistance for Plant Defense: A Sus-tainable Approach to Protection, Oxford, Blackwell, Publishing Ltd., 2007, pp. 179-200.

9. Zaharenko V.A. Zashchita i karantin rastenij, 2003. № 5, pp. 49-50.

10. Yurchenko O.S., Selickaya O.G., Burov V.N., Tyuterev S.L. Entomolo-gicheskoe obozrenie, 2004.V. 83, № 4, pp. 808-815.

11. Kirillova O.S., Selickaya O.G. Vestnikzashchity rastenij, 2015. № 1 (83), pp. 58-62.

12. Tyuterev S.L. Vestnik zashchity rastenij, 2015. № 1 (83), pp. 3-13.

13. Vlasenko N.G., Malyuga A.A., Egorycheva M.T. et al. Biologicheskaya zashchita rastenij-osnova stabilizacii agroehkosistem [Biological Plant Protection - the basis for the stabilization of agroecosystems]. Krasnodar, 2012. Issue 7, pp. 314-316.

14. Vakulenko V.V. Zashchita i karantin rastenij, 2015. № 3. P. 43.

15. Gvozdenac S., Indie D., Vukovic S. et al. Botanical insecticides and their use in plant protection. Bitjni Lekar, 2013. Vol. 41, № 5, pp. 548-557. 
16. Gar K.A. Metody ispytaniya toksichnosti i ehffektivnosti pesticidov [Test methods for the toxicity and effectiveness of pesticides]. M., 1963. $286 \mathrm{p}$.

17. Dospekhov B.A. Metodika polevogo opyta [Field experience]. M.: Kolos, 1986. $502 \mathrm{p}$.

18. Pavlovskij E.N. Fauna SSSR. M.-L., 1959. V. 1. №. 1. Part 1. 202 p.

19. Blagoveshchenskij D.I. Metody issledovaniya vshej (Siphunculata) [Methods of research lice (Siphunculata)]. L.: Nauka. 1972. 88 p.

20. Volskis G.I. Metodiki issledovaniya produktivnosti i struktury vidov ptic v predelah ih arealov [Methods for studying the productivity and structure of bird species within their ranges]. Vilnyus, 1977. Part 1, pp. 121-127.

21. Dezinsekciya: Metody opredeleniya ehffektivnosti insekticidov, aka-ricidov, regulyatorov razvitiya i repellentov, ispolzuemy $h$ vedicinskoj dezinsekcii [Disinsection: Methods for determining the effectiveness of insecticides, acaricides, development regulators and repellents used in medical disinsection]. M., 2003. 87 p.

\section{ДАННЫЕ ОБ АВТОРАХ}

Шаманская Любовь Демьяновна, ведущий научный сотрудник, д. с.-х. н. ФГБНУ «Федеральный Алтайский научный центр агробиотехнологий» Научный городок, 35, г. Барнаул, 656910, Российская Федераџия shamanskayald@gmail.com

Бутаков Евгений Иванович, научный сотрудник, к.б.н ФГБНУ «Федеральный Алтайский научный центтр агробиотехнологий» Научный городок, 35, г. Барнаул, 656910, Российская Федерация aniish@mail.ru

\section{DATA ABOUT THE AUTHORS}

Shamanskaya Lubov Demianovna, Leading Researcher, Doctor of Agronomical Sciences

Altai Federal scientific center of agrobiotechnology

shamanskayald@gmail.com

SPIN-code: 3176 -8941

Butakov Evgenii Ivanovich, Research Assistant, Candidate of Biology

Altai Federal scientific center of agrobiotechnology

35, Scientific village, Barnaul, 656910, Russian Federation

aniish@mail.ru

SPIN-code: 9496-7944 